\title{
ASSESSMENT OF BIOSOLIDS IN EARTHWORM CHOICE TESTS WITH DIFFERENT SPECIES AND SOILS
}

\author{
N. ARTUSO ${ }^{1,2}$ \\ T.F. KENNEDY ${ }^{\ddagger}$ \\ J. CONNERY ${ }^{1}$ \\ J. GRANT ${ }^{3}$ \\ O. SCHMIDT ${ }^{2}$
}

Received: $18 / 06 / 10$

Accepted: 22/12/10

\author{
${ }^{1}$ Teagasc, Oak Park Research Centre, Carlow, Ireland \\ ${ }^{2}$ UCD School of Agriculture, \\ Food Science \& Veterinary Medicine, \\ University College Dublin, Belfield, Dublin 4, Ireland \\ ${ }^{3}$ Teagasc, Kinsealy Research Centre, \\ Malahide Road,Dublin 17, Ireland
}

*to whom all correspondence should be addressed: e-mail: tom.kennedy@teagasc.ie

\begin{abstract}
Earthworm avoidance response is a new tool for rapid and efficient screening of potentially toxic substances added to soil environments. This technique was used to determine if five common, ecologically different earthworm species (Allolobophora chlorotica, Aporrectodea longa, Aporrectodea caliginosa, Eisenia fetida and Lumbricus terrestris) avoid soils amended with six biosolids (treated sewage sludge) applied at rates equivalent to realistic field rates of $0,2,5,10$ and $20 \mathrm{t} \mathrm{ha}^{-1}$. The results showed that $A$. chlorotica, E. fetida and $L$. terrestris were attracted by low concentrations of biosolids $\left(2 \mathrm{t} \mathrm{ha}^{-1}\right)$, whereas they avoided the highest concentration $\left(20 \mathrm{t} \mathrm{ha}^{-1}\right)$. The other species did not show any preferences. An additional treatment comparing the behaviour of $E$. fetida in natural and artificial soil suggested that the type of soil can alter the preference of earthworms. Comparisons of behavioural and actual toxicity data for the same six biosolids suggest that avoidance responses by earthworms are sensitive enough to reflect different toxicities of biosolids. It is concluded that earthworm avoidance behaviour offers an ecologically relevant tool for screening the deleterious rate-effect of biosolid amended soils.
\end{abstract}

KEYWORDS: avoidance-test, earthworms, biosolids, E. fetida, treated sewage sludges.

\section{INTRODUCTION}

Sewage sludge generation and waste management is one of the most important environmental issues society has to tackle. Agricultural land application is the most commonly used method for sludge disposal (Gray, 2005). However, the disposal of sludge on land as fertilizer is associated with environmental problems due to the presence of nutrients and various toxicants such as heavy metals and pathogens that can contaminate soils, ground and surface water (Ozores-Hampton et al., 2005).

European and Irish law (Council Directive 86/278/EEC; S.I. 183/1991; S.I. 148/1998; S.I. 267/2001; S.I. 378/2006) aim to promote the recycling of municipal sludge in agriculture and to set standards to protect the environment and food quality. European legislation which regulates sewage sludge amendments in agriculture land (86/271/ECC) or influence indirectly their use (91/676/ECC) imposes heavy metal limits values and nitrate/phosphorus regulation.

In recent years, different technologies have been developed for the treatment and decontamination of sludge prior to the use on land (Lo and Chen, 1990; Metcalf and Eddy, 2003; Strasser et al., 1995). Biosolids, also known as treated or stabilized sewage sludge, are the final products of urban wastewater treatments employing standardised technologies. The amount of Biosolids applied to an agricultural land is dictated by their heavy metals and nutrient content (nitrogen and phosphorus) and by the crop demands.

However, it is also paramount to know what the ecological impacts of biosolids are likely to be on soil organisms, their diversity and their functions. Various ecotoxicologial methods have been used 
to test such ecological impacts of sewage sludges on soil using soil invertebrates (Butt, 1999; Domene et al., 2008; Pandard et al., 2006; Conteras-Ramos et al., 2009; Carbonell et al., 2009) and in particular avoidance tests were performed with earthworms (Moreira et al., 2008; Natal-da-Luz et al., 2009; Kobetičová et al., 2010). Based on feeding habits, earthworms are dived in two main ecological categories, detritivores and geophages (Curry and Schmidt, 2007). Detritivores are divided into two groups, the epigeics which are restricted to organic-rich horizons (litter or surface dwellers and compost worms), such as Eisenia fetida, and anecics which live in vertical burrows in the soil profile but feed preferentially on surface litter (deep burrowers), including Aporrectodea longa and Lumbricus terrestris (Bouché, 1977). Geophages (endogeics sensu Bouché, 1977) feed on the mineral soil and they produce mostly horizontal galleries near the soil surface, such as Aporrectodea caliginosa and Allolobophora chlorotica (Curry, 1994).

Acute chemical sensitivity chemoreceptors and dispersion ability give earthworms capabilities for avoiding unfavourable micro-habitats (Stephenson et al., 1998). Recently, different avoidance responses of earthworm species to selected chemicals have been reported (Lukkari et al., 2005; Garcia et al., 2008), suggesting that tests based on avoidance behaviour have great potential to give quick and ecologically relevant information in risk assessment procedures. Research is required to develop, validate and standardise these methods.

The overall objective of the present study was to develop earthworm avoidance tests for biosolid toxicity screening. The specific aims were as follows: 1) to evaluate the potential of using different earthworm species ( $E$. fetida, A. caliginosa, A. chlorotica, A. longa and L. terrestris) to assess the toxicity of five biosolids; 2) to compare the efficiency of new avoidance tests and established reproduction tests; 3 ) to investigate the avoidance behaviour of $E$. fetida to biosolid amendments in two different substrates: natural and artificial soils.

\section{METHODS}

\subsection{Test substrate}

Biosolids from five treatment plants (sources) throughout Ireland and one plant in Pueblo, Colorado, USA, were investigated for their effects on five different earthworm species. The sources of Biosolids were; Biosolid 1 Dublin (Ringsend), Biosolid 2 Waterford (Dungarvan), Biosolid 3 Cork (Little Island), Biosolid 4 Limerick (Dunlickey), Biosolid 5 Kildare (Osberstown) and Biosolid 6 USA (Colorado). All Irish Biosolids, 160 litres each, were collected during July 2007 and stored in sealed plastic drums. The USA Biosolid was obtained in 2008 and was stored at room temperature. Drying temperatures and dryer type used in the production of each Biosolid are given in Table 1. Chemical analysis of each Biosolid was obtained by means of Inductively Coupled Plasma Mass Spectrometry (ICP-MS), detailed results are reported by Artuso et al. (2010).

Table 1. Biosolid production temperatures $\left({ }^{\circ} \mathrm{C}\right)$, dry matter content and dryer type

\begin{tabular}{|c|c|c|c|c|c|c|}
\hline & Biosolid 1 & Biosolid 2 & Biosolid 3 & Biosolid 4 & Biosolid 5 & Biosolid 6 \\
\hline Dryer temp. & $350-450$ & $350-450$ & $118-175$ & $275-325$ & $120-130$ & Air temp \\
\hline $\begin{array}{l}\text { largeted dry } \\
\text { matter (\%) }\end{array}$ & $>94$ & $>94$ & $>94$ & $>94$ & $>94$ & - \\
\hline $\begin{array}{l}\text { Measured } \\
\text { dry matter } \\
(\%)\end{array}$ & 95.4 & 97.5 & 89.6 & 94 & 95.1 & 82.1 \\
\hline Dryer type & $\begin{array}{l}\text { Rotating } \\
\text { drum }\end{array}$ & $\begin{array}{l}\text { Rotating } \\
\text { drum }\end{array}$ & $\begin{array}{l}\text { Thin-film } \\
\text { evaporator }\end{array}$ & $\begin{array}{l}\text { Rotating } \\
\text { drum }\end{array}$ & $\begin{array}{l}\text { 3-stage } \\
\text { Belt }\end{array}$ & Filter-press \\
\hline
\end{tabular}

\subsection{Test organisms}

The test organisms were adults of earthworm species collected at Teagasc Oak Park, Research Centre, (Carlow, Ireland): Allolobophora chlorotica (Savigny, 1826), Aporrectodea longa (Ude, 1885), Aporrectodea caliginosa (Savigny, 1826) and Lumbricus terrestris (L.) (juveniles and adult) were extracted from a unpolluted minimum tillage field (details below) using the mustard oil method (a mix of $2 \mathrm{ml}$ allyl isothiocyanate and $40 \mathrm{~mL}$ isopropanol [2-propanol], added to $20 \mathrm{I}$ of water just before application in the field) and rinsed thoroughly in water immediately after the extraction. Eisenia fetida (Savigny, 1826) was produced in culture as recommended by ISO 11268-2 (1998). 


\subsection{Avoidance test}

The avoidance test was conducted as described by ISO protocol (ISO/FDIS 17512-1).

Two different types of soil were used for the experiment: artificial and natural soil. The artificial soil used in tests comprised Sphagnum peat 10\% (sieved through $5 \mathrm{~mm}$ mesh), $20 \%$ kaolinite and $70 \%$ quartz sand ( $80 \%$ particle size 0.2 to $2 \mathrm{~mm}$ ) (ISO 1998 11268-2, ISO 1999 11267). The water holding capacity (WHC) of the soil was adjusted to $68 \%$ using distilled water and the $\mathrm{pH}$ to 6.0 , using calcium carbonate. The natural soil was obtained from the same field from which earthworms were collected. Soil from the surface to a depth of $20 \mathrm{~cm}$ was used. Soil was air dried in a glasshouse and sieved through $3 \mathrm{~mm}$ mesh. The soil type is described as Baggotstown-Carlow Complex; this is a moderately deep, free-draining Brown Earth derived from limestone gravels with sandy loam texture. The preceding crops on the site were five winter wheat crops preceded by three winter barley crops, three spring barleys, prior to which was winter barley which was preceded by a grass ley. Soil analysis showed: $\mathrm{pH} 6.62$, phosphorous $13.5 \mathrm{mg} \mathrm{l}^{-1}$, potassium $102.7 \mathrm{mg} \mathrm{l}^{-1}$, magnesium $131.8 \mathrm{mg}$ $\mathrm{I}^{-1}$, copper $2.1 \mathrm{mg} \mathrm{I}^{-1}$, manganese $209.5 \mathrm{mg} \mathrm{I}^{-1}$ and zinc $1.5 \mathrm{mg} \mathrm{I}^{-1}$. Soil nitrogen was very low with a requirement of $190 \mathrm{~kg} \mathrm{ha}^{-1}$ for winter wheat.

Plastic containers, $20 \times 12 \times 5 \mathrm{~cm}$, were used for each trial replicate. Containers had a removable aluminium flat sheet which divided the container transversely into two equal volumes. Two hundred and fifty grammes of dried field soil was introduced into the control section of the container (marked left side) while a similar weight of field soil-biosolid mixture was added to the test section (marked right side).

Three rates of biosolids equivalent to 2, 10 and $20 \mathrm{t} \mathrm{ha}^{-1}$ were mixed with the soil substrate. Every species was tested singularly and $L$. terrestris was tested for adults and juveniles separately. Ten clitellate worms of $A$. chlorotica, $A$. caliginosa and $E$. fetida were placed per box, five adults for $A$. caliginosa, four for $L$. terrestris and two for $A$. longa. Replication was 5 -fold except for $E$. fetida tests which was 6-fold. Worm species and number as well as trial replication, biosolid source and rate and soil type are given in Table 2. The substrate-biosolid mix was moistened, using distilled water, so that no free water was visible when the soil was compressed (ISO 17512-1 2005). Worms were placed on the line dividing the two sections following removal of the aluminium divider. Perforated snap-on plastic lids were placed on containers. Containers were placed in a controlled environment cabined (CEC) for 2 days at $20^{\circ} \mathrm{C}$ in a $16: 8 \mathrm{~h}$ light: dark regime. After this period, the control and test soils were separated and the number of earthworms in each section counted as described in ISO (2005).

Table 2. Earthworm species and number investigated in 'avoidance' tests using soils with and without biosolids. Trial replication, biosolid number (source), soil source and equivalent field rates of application investigated are also shown

\begin{tabular}{lccccc}
\hline \multicolumn{1}{c}{ Species } & $\begin{array}{c}\text { Worms per } \\
\text { container }\end{array}$ & Replication & Biosolids & $\begin{array}{c}\text { Rates } \\
\left(\mathrm{t} \mathrm{ha} \mathbf{1}^{-1}\right)\end{array}$ & Soil \\
\hline E. fetida & 10 & 6 & $1,2,3,4,5,6$ & $2,10,20$ & $\begin{array}{c}\text { Natural } \\
\text { E. fetida }\end{array}$ \\
& 10 & 6 & $1,2,3,4,5,6$ & $2,10,20$ & Artificial \\
A. chlorotica & 10 & 5 & $1,2,3,4,5$ & $2,10,20$ & Natural \\
& 4 & 5 & $1,2,3,4,5$ & 2,10 & Natural \\
L. terrestris & 5 & 5 & $1,2,3,4,5$ & 20 & Natural \\
L. terrestris & 5 & 5 & 1,3 & 2,10 & Natural \\
L. terrestris* & 5 & 5 & 1,3 & 2,10 & Natural \\
A. caliginosa & 5 & 5 & 1,3 & 2,10 & Natural \\
A. longa & 2 & 5 & & &
\end{tabular}


Table 3. Eisenia fetida preference between soil (control) and soil amended with biosolids from six locations and applied at three rates, laboratory 'avoidance test'. Ten adult worms for each replicate which was 6 -fold.

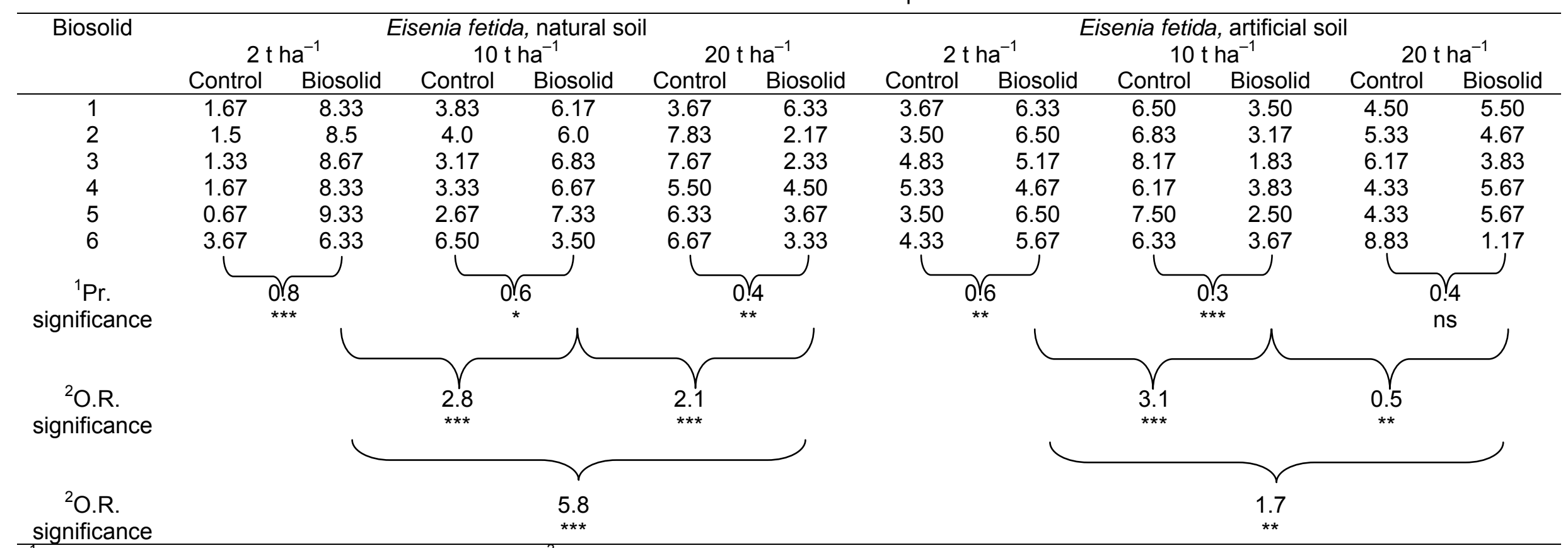

significance

${ }^{2}$ Odds Ratio i.e. The number of times a worm is more likely to be found in biosolid relative to control.

${ }^{*}=\mathrm{P}<0.05,{ }^{* *}=\mathrm{P}<0.01,{ }^{* * *}=\mathrm{P}<0.001$.

Table 4. The number of Eisenia fetida recovered from each biosolid amended soil and untreated control soils for combined rates of biosolids $(2,10$ and

$20 \mathrm{t} \mathrm{ha}^{-1}$ ) and combined controls. The probability and significance of finding worms in biosolid amended natural and artificial soil is presented.

\begin{tabular}{|c|c|c|c|c|c|c|c|c|}
\hline \multirow[b]{2}{*}{ Biosolid } & \multicolumn{4}{|c|}{ Natural soil } & \multicolumn{4}{|c|}{ Artificial soil } \\
\hline & Control & Biosolid & ${ }^{\mathbf{1}}$ Pr. & Signif. & Control & Biosolid & Pr. & Signif. \\
\hline 1 & 9.2 & 20.8 & 0.71 & $\star * \star$ & 14.7 & 15.3 & 0.51 & n.s. \\
\hline 2 & 13.3 & 16.7 & 0.56 & n.s. & 15.7 & 14.3 & 0.47 & n.s. \\
\hline 3 & 12.2 & 17.8 & 0.60 & $*$ & 19.2 & 10.8 & 0.35 & $* *$ \\
\hline 4 & 10.5 & 19.5 & 0.66 & $* * *$ & 15.8 & 14.2 & 0.47 & n.s. \\
\hline 5 & 9.7 & 20.3 & 0.64 & $* *$ & 15.3 & 14.7 & 0.48 & n.s. \\
\hline 6 & 16.8 & 13.2 & 0.42 & n.s. & 19.5 & 10.5 & 0.34 & $* * *$ \\
\hline
\end{tabular}

${ }^{1}$ Probability of worm being in biosolid amended soil. $\quad{ }^{*}=\mathrm{P}<0.05,{ }^{* *}=\mathrm{P}<0.01, \quad{ }^{* * *}=\mathrm{P}<0.001$. 


\subsection{Data analysis}

The binary outcomes of the avoidance tests were analysed using a generalized linear mixed model. Random effects were used to model the correlations within each test, i.e. the binary outcomes for each worm were not taken as independent within tests. Proc Glimmix (Statistical Analysis Systems Institute SAS 9.1 2004) was used to fit the analysis models. Analysis was carried out for each species separately and biosolid source was a blocking factor. Comparisons between levels of the blocking factor were not supported by randomisation and therefore the p-values are used only as a guide to exploring these differences. Multiple comparison procedures were used to control error rates in pairwise comparisons. Odds ratios were used to summarise the differences in the binary outcomes where an odds ratio of one means no difference, e.g. a worm is one times as likely to be found in the biosolid-amended mixture compared to unamended soil, that is, equally likely to be found in either.

\section{RESULTS}

\subsection{Eisenia fetida}

Comparing the numbers of $E$. fetida recovered from natural soil and natural soil amended with biosolids at the $2 \mathrm{t} \mathrm{ha}^{-1}$ rate showed that worms had a significant $(p<0.0001)$ preference for biosolid amended soil compared to untreated control soil (Table 3 ). The probability of finding a worm in the amended soil was $80 \%$. Worms also had a significant $(p=0.02)$ preference for the amended soil at the $10 \mathrm{tha}^{-1}$ rate with a $60 \%$ probability of worms being found in the amended soil. At the $20 \mathrm{t} \mathrm{ha}^{-1}$ rate, however, worms had a significant $(p=0.006)$ preference for the untreated soil with only a $40 \%$ probability of finding worms in the amended soil. In the case of biosolid amended natural soil, increasing the rate of biosolid application resulted in significantly $(p<0.0001)$ fewer worms in the amended soils. At the $2 \mathrm{t} \mathrm{ha}^{-1}$ rate, amended soil had significantly $(p<0.0001)$ more worms than either the 10 or $20 \mathrm{t} \mathrm{ha}^{-1}$ rate; similarly, the $10 \mathrm{t} \mathrm{ha}^{-1}$ rate had significantly $(p=0.0005)$ more worms than the $20 \mathrm{t} \mathrm{ha}^{-1}$ rate (Table 3).

Comparisons of overall E. fetida preferences for amended and control soils for individual biosolids are presented in Table 4. The $p$-values are the result of a test of the measured probability versus 0.5 , i.e, equally likely to be found in either material. The Worms had a significant preference for amended natural soil for biosolid $1(71 \%)$, biosolid $3(60 \%)$, biosolid $4(66 \%)$ and biosolid $5(64 \%)$. Worm numbers did not differ significantly between amended and control soils for either biosolid 2 and biosolid 6 (Table 4). Data analysis of worm numbers in natural soil amended with one of the six biosolids (blocking factor comparisons) showed biosolid 6 had significantly fewer worms than either biosolid 1 or biosolid 4 . Differences between the remaining biosolids were not significant.

In the case of artificial soil amended with biosolids, there were significantly $(p=0.01)$ more $E$. fetida in the amended soil at the $2 \mathrm{t} \mathrm{ha}^{-1}$ rate relative to the controls (Table 3). However, at the $10 \mathrm{t} \mathrm{ha}^{-1}$ rate there were significantly $(p<0.0001)$ more worms in the controls than in the amended soil. There were also more worms in the controls relative to the amended soil at the $20 \mathrm{t} \mathrm{ha}^{-1}$ rate, however, the latter difference was not significant. Comparing worm preferences for amended artificial soil at the different rates showed worm numbers were significantly $(p<0.0001)$ greater for the $2 \mathrm{tha}^{-1}$ rate than the $10 \mathrm{tha}^{-1}$ rate and $20 \mathrm{tha}^{-1}$ rate $(\mathrm{p}=0.006)$. Unexpectedly, artificial soil amended with biosolid at the $20 \mathrm{t} \mathrm{ha}^{-1}$ rate had significantly $(p=0.007)$ more worms than that for the $10 \mathrm{t} \mathrm{ha}^{-1}$ rate.

Comparison of overall E. fetida preference for amended and control artificial soil for individual biosolids are given in Table 4. There was no significant difference in the number of worms recorded between the control and amended soil for biosolid 1,2, 4 and 5, while significantly fewer worms were found in soil amended with biosolid $3(p=0.002)$ and biosolid $6(p=0.001)$. Data analysis of worm numbers in artificial soil amended with any one of the six biosolids showed that worms did not have a significant preference between biosolids. The comparison between the artificial and the natural soils showed the number of worms was significantly higher $(p<0.0001)$ in the natural soil than in the artificial at the 2 and $10 \mathrm{tha}^{-1}$ rates, whereas at $20 \mathrm{tha}^{-1}$ there was no significant difference between the two soils.

\subsection{Allolobophora chlorotica}

Data analysis incorporating results for all five Irish biosolids showed there were significantly $(p<0.0001)$ more $A$. chlorotica in natural soil amended with biosolids relative to control soil at 2 and $10 \mathrm{t} \mathrm{ha}^{-1}$ rate (Table 5). At the $20 \mathrm{t} \mathrm{ha}^{-1}$ rate, however, the amended soil had significantly fewer worms than the control soil. In the case of biosolid amended natural soil, increasing the rate of 
biosolid application resulted in significantly $(p<0.0001)$ fewer worms in the amended soils. At the $2 \mathrm{t}$ $\mathrm{ha}^{-1}$ rate, amended soil had significantly $(\mathrm{p}=0.0001)$ more $A$. chlorotica than either the 10 or $20 \mathrm{t} \mathrm{ha}^{-1}$ rates (Table 5). Similarly, the $10 \mathrm{tha}^{-1}$ rate had significantly more worms than the $20 \mathrm{t} \mathrm{ha}^{-1}$ rate. The odds ratio showed worms were 16 times more likely to be found in amended soil at 10 rather than 20 $\mathrm{t} \mathrm{ha}^{-1}$ rate. Comparing the number of worms recovered from amended soil for each biosolid with that for untreated controls showed only biosolid 3 had significantly $(p=0.008)$ fewer worms than that for the control. Comparisons between biosolids showed biosolid 3 had significantly fewer worms than the remaining four.

Table 5. Allolobophora chlorotica preference between soil (control) and soil amended with biosolids from five Irish locations and applied at three rates, laboratory 'avoidance test'. Ten adult worms for each of the six replicates

\begin{tabular}{|c|c|c|c|c|c|c|}
\hline \multirow[t]{3}{*}{ Biosolid } & \multicolumn{6}{|c|}{ Allolobophora chlorotica, natural soil } \\
\hline & \multicolumn{2}{|c|}{$2 \mathrm{tha}^{-1}$} & \multicolumn{2}{|c|}{$10 \mathrm{tha}^{-1}$} & \multicolumn{2}{|c|}{$20 \mathrm{t} \mathrm{ha}^{-1}$} \\
\hline & Control & Biosolid & Control & Biosolid & Control & Biosolid \\
\hline 1 & 0.2 & 9.8 & 0.6 & 9.4 & 8.4 & 1.6 \\
\hline 2 & 0.8 & 9.2 & 2.8 & 7.2 & 8.2 & 1.8 \\
\hline 3 & 1.6 & 8.4 & 6.6 & 3.4 & 9.6 & 0.4 \\
\hline 4 & 0.8 & 9.2 & 1.0 & 9.0 & 4.8 & 5.2 \\
\hline 5 & 0.4 & 9.6 & 2.6 & 7.4 & 8.8 & 1.2 \\
\hline $\begin{array}{c}{ }^{1} \mathrm{Pr} . \\
\text { sianificance }\end{array}$ & & & & & & \\
\hline $\begin{array}{c}{ }^{2} \mathrm{O} . \mathrm{R} . \\
\text { significance }\end{array}$ & & & 5.6 & & $\begin{array}{c}16.2 \\
* * *\end{array}$ & \\
\hline $\begin{array}{c}{ }^{2} \mathrm{O} . \mathrm{R} . \\
\text { significance }\end{array}$ & & & & $\frac{90.9}{* * *}$ & & \\
\hline
\end{tabular}

${ }^{1}$ Probability of worm being in biosolid.

${ }^{2}$ Odds Ratio i.e. The number of times a worm is more likely to be found in biosolid relative to control.

${ }^{*}=\mathrm{P}<0.05,{ }^{* *}=\mathrm{P}<0.01,{ }^{* * *}=\mathrm{P}<0.001$.

\subsection{Lumbricus terrestris}

As with other worm species, adult $L$.terrestris worms had a significant $(p=0.006)$ overall preference for biosolid amended soils relative to untreated control soil at $2 \mathrm{t} \mathrm{ha}^{-1}$ application rate (Table 6). At the $10 \mathrm{t} \mathrm{ha}^{-1}$ rate, $L$. terrestris did not show a preference for amended soil relative to control soil. However, at the $20 \mathrm{t} \mathrm{ha}^{-1}$ rate, worms had a significant $(p<0.0001)$ preference for untreated relative to amended soil. Comparing worm preference for amended soil at 2,10 and $20 \mathrm{tha}^{-1}$ rates showed the $2 \mathrm{t} \mathrm{ha}^{-1}$ rate had non-significant $(p<0.0001)$ more than for the $20 \mathrm{t} \mathrm{ha}^{-1}$ rate. Amended soil at the $10 \mathrm{t} \mathrm{ha}^{-1}$ rate had significantly $(p=0.01)$ more worms than the $20 \mathrm{t} \mathrm{ha}^{-1}$ rate. Data analysis across all rates for the five biosolids showed soils amended with biosolid 2 and biosolid 3 had significantly fewer $L$. terrestris when compared with untreated soil. Comparisons between biosolids showed soil amended with biosolid 1 had significantly more worms than soil amended with either biosolid $2(p=0.007)$ and biosolid $3(p=0.008)$.

In the case of juvenile $L$. terrestris, amended soils included only the 2 and $10 \mathrm{t} \mathrm{ha}^{-1}$ rates. Juvenile $L$. terrestris had a significant $(p=0.004)$ preference for biosolid (aggregate data for biosolids 1 and 3 ) amended soil when compared with control soil. Juvenile worms were $83 \%$ more likely to be found in the amended soil (Table 6 ) Worms did not show a preference between amended soil and control soil when biosolids were applied at $10 \mathrm{t} \mathrm{ha}^{-1}$ rate. Juveniles had a significant $(p=0.01)$ preference for amended soil at the $2 \mathrm{t} \mathrm{ha}^{-1}$ rate relative to that for the $10 \mathrm{t} \mathrm{ha}^{-1}$ rate. Comparisons between soil amended with biosolid 1 and 3 showed worms had a significant preference for the biosolid 1 mixture. 
Table 6. Lumbricus terrestris preference between soil (control) and soil amended with biosolids from five Irish locations and applied at three rates, laboratory 'avoidance test'. Four adult worms and five juvenile worms were used for each of six replicates

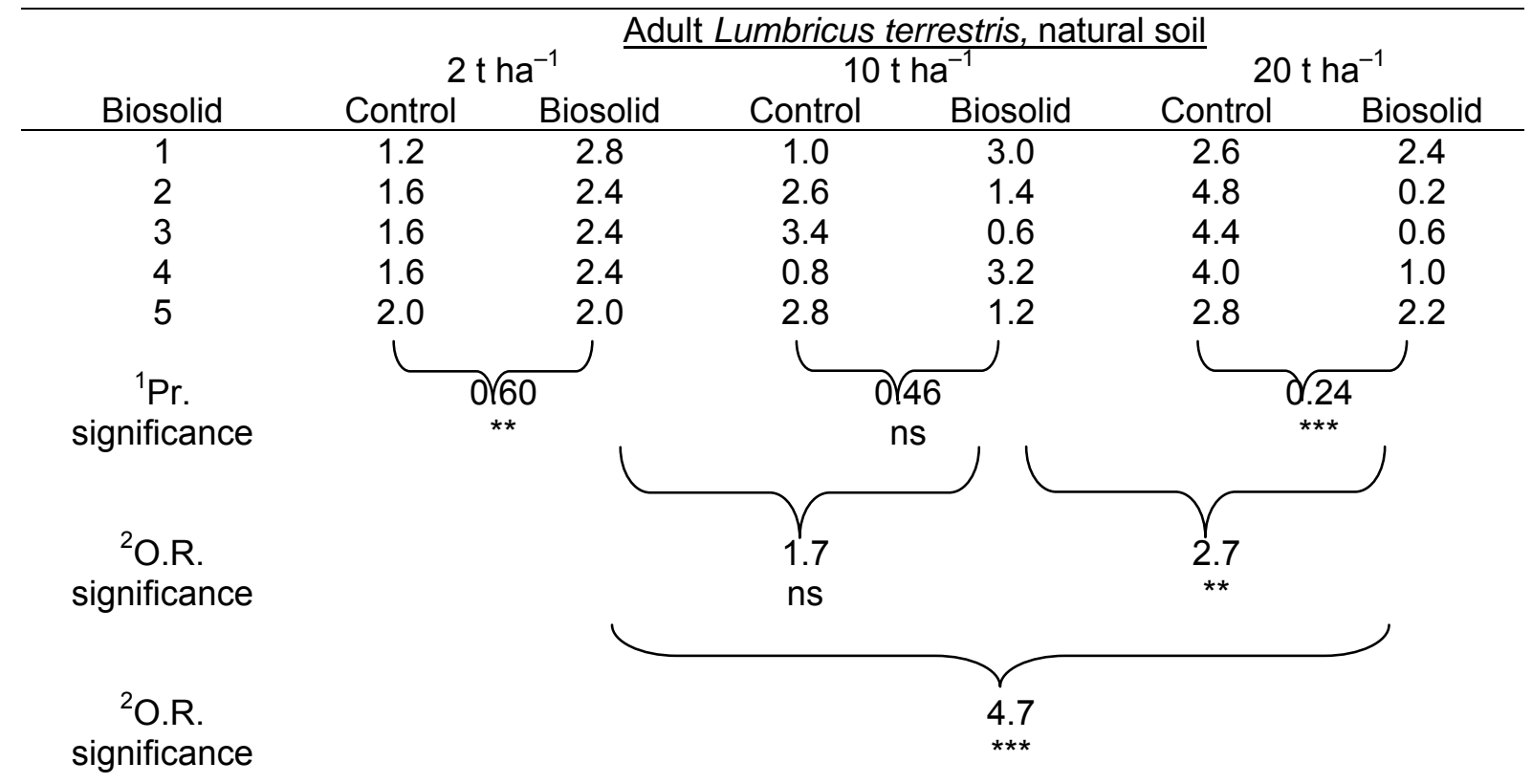

\begin{tabular}{|c|c|c|c|c|}
\hline \multirow[b]{3}{*}{ Biosolid } & \multicolumn{4}{|c|}{ Juvenile Lumbricus terrestris, natural soil } \\
\hline & \multicolumn{2}{|c|}{$2 \mathrm{tha}^{-1}$} & \multicolumn{2}{|c|}{$10 \mathrm{tha}^{-1}$} \\
\hline & Control & Biosolid & Control & Biosolid \\
\hline 1 & 0.8 & 4.2 & 1.6 & 3.4 \\
\hline 3 & 1.0 & 4.0 & 3.6 & 1.4 \\
\hline $\begin{array}{c}{ }^{1} \mathrm{Pr} . \\
\text { significance }\end{array}$ & & & & \\
\hline $\begin{array}{c}{ }^{2} \mathrm{O} . \mathrm{R} . \\
\text { significance }\end{array}$ & & & $\begin{array}{l}5.5 \\
* *\end{array}$ & \\
\hline
\end{tabular}

${ }^{1}$ Probability of worm being in biosolid.

${ }^{2}$ Odds Ratio i.e. The number of times a worm is more likely to be found in biosolid relative to control.

${ }^{*}=\mathrm{P}<0.05, \quad{ }^{* *}=\mathrm{P}<0.01, \quad{ }^{* * *}=\mathrm{P}<0.001$.

\subsection{Apporectodea caliginosa and A. longa}

Investigations involving Aporrectodea longa and A. caliginosa (details in Table 2) did not indicate differences in worm preferences between amended and control soils with either biosolid 1 or biosolid 3 , for the two application rates of 2 and $10 \mathrm{tha}^{-1}$ (data not shown).

\section{DISCUSSION}

\subsection{Earthworm preference and biosolids toxicity}

Results of avoidance test with A. chlorotica, E. fetida and L. terrestris clearly showed that earthworms make a choice when offered unamended control soil and soil amended with biosolids. This confirms that the principle of these tests is suited to determining the preference by soil invertebrates for or avoidance of soils containing exogenous materials (Hund-Rinke and Wiechering, 2001; Yeardley et al., 1996). Results showed that the species reacted similarly to biosolids amendments: they all were attracted by low concentrations of biosolids $\left(2 \mathrm{t} \mathrm{ha}^{-1}\right)$, whereas they avoided the highest concentration $\left(20 \mathrm{t} \mathrm{ha}^{-1}\right)$. As suggested by Hamilton et al. (1988), low rates of 
biosolids probably attracted earthworms as a food source because of its higher organic matter content compared with the untreated controls. The same behaviour was observed by Natal-da-Luz et al. (2009) and Moreira et al. (2008) when E. andrei earthworms were added to artificial soil mixed with $6 \mathrm{t} \mathrm{ha}^{-1}$ urban sewage sludge. However, Natal da Luz et al. (2009) found that worms were still attracted by sewage sludge when applied at 25 and $45 \mathrm{t} \mathrm{ha}^{-1}$, whereas, in this study at $20 \mathrm{t} \mathrm{ha}^{-1}$ rate all the three species avoided the amended soil.

The repulsive effect observed when biosolids were applied at $20 \mathrm{tha}^{-1}$ has to be interpreted carefully since it may be related not just to the toxicity of the material tested but also to the artificial conditions of the experiment such as release of ammonia and decrease in $\mathrm{pH}$ (Crouau et al., 2002). These other conditions that could act as stimuli affecting earthworm behaviour should be monitored in future studies.

The results from comparisons of 6 biosolids indicate that avoidance responses by earthworms are sensitive enough to reflect different toxicities of different biosolids. The avoidance behaviour observed at $20 \mathrm{t} \mathrm{ha}^{-1}$ may be attributed to the high levels of zinc and copper measured in the five Irish biosolids (between 202 and $530.7 \mu^{-1} \mathrm{~g}^{-1}$ for copper and between 83.4 and $681 \mathrm{\mu g} \mathrm{g}^{-1}$ for zinc). A pronounced avoiding behaviour was observed in treatments with biosolids 2 and 3 where the concentration of zinc was particularly high $\left(547\right.$ and $\left.681 \mu^{-1} \mathrm{~g} \mathrm{~g}^{-1}\right)$. Considering the results obtained by Lukkari et al. (2005) for the effects of Cu/Zn concentration pairing on Aporrectodea tuberculata avoidance behaviour, the level of $\mathrm{Cu} / \mathrm{Zn}$ present at the higher concentrations of soil-biosolids mixtures were high enough to affect the avoidance behaviour of the earthworms.

\subsection{Method development and comparisons}

Comparing the behaviour of $E$. fetida in artificial and natural soils to which biosolids at various rates were added showed similar results for the two soils at $2 \mathrm{t} \mathrm{ha}^{-1}$ rate, whereas a dissimilar responses were recorded at 10 and $20 \mathrm{t} \mathrm{ha}^{-1}$. At $10 \mathrm{t} \mathrm{ha}^{-1}$ in natural soil earthworms chose the biosolid amended section, while in the artificial soil they preferred the controls. The movement of the test organisms toward the amended soil when biosolids where added at $2 \mathrm{t} \mathrm{ha}^{-1}$ is probably related to the absence of repulsive effect of the contaminants in the biosolids. However, soil properties such as $\mathrm{pH}$ and organic matter content can affect the avoidance behaviour of soil organisms (Amorim et al., 2005; 2008; Natal da Luz et al., 2004). In this study, the pH levels of the soils were similar (6.5 in the artificial soil, 6.0-7.0 in the field soil), while the artificial soil had a higher organic matter content than the field soil used (10\% in the artificial soil, $6.4 \%$ field soil). We can hypothesize that in artificial soil, E.fetida was finding enough food in the control section whereas in natural soil, the low content of organic matter encouraged them to seek out food in the biosolid amended section. The central issues in using field soil - standardisation and inter-test comparability - have been addressed by other authors (Römbke and Amorim, 2004).

The ecological differences of the earthworms species employed in this study were expected to influence the outcome of the avoidance tests (Doube et al., 1997; Lukkari and Haimi, 2005). Tomlin (1992), in fact, suggested that ecological characteristics of earthworm species (epigeic, anecic and endogeic) may affect their susceptibility to soil contaminants. E. fetida is considered to be less sensitive to soil factors than other earthworm species (Spurgeon et al., 2000; Lukkari et al., 2005; Frampton et al., 2006; Owojori and Reinecke, 2009). However, in this study there was no evidence of different behavioural patterns between earthworm species. These results indicate the suitability of E. fetida as standard species for ecotoxicological tests (Kobetičová et al., 2010), since it is easily produced in laboratory conditions and it had similar responses to biosolids applications as the other soil-dwelling species that occur in agricultural soils such as $L$. terrestris and $A$. caliginosa. This assumption is supported by Langdon et al. (2005) who determined the effect of lead on survival and avoidance response of $E$. andrei, $L$. rubellus and $A$. caliginosa, in a standard artificial soil. Little or no variations among the three ecologically different earthworms species were observed in the avoidance test results.

The main trends observed for $E$. fetida in the avoidance tests, were also detected in ISO Mortality and Reproduction tests performed with the same biosolids (Artuso et al., 2010). Lukkari et al. (2005) observed that $A$. tuberculata avoided contaminated soil at lower metal concentrations than those level that induced significant negative responses in the acute and reproduction test. The results of this study showed the high sensitivity of this simple and rapid preference test, including at lower application rate $\left(2 \mathrm{t} \mathrm{ha}^{-1}\right)$ of biosolids which are realistic for field situation. Several studies indicated a similar or higher sensitivity of avoidance test compared with sub-lethal measures (Hund-Rinke et 
al., 2005; Hund-Rinke and Wiechering, 2001; Schaefer, 2003; Owojori and Reinecke, 2009). However, in risk assessment studies where the toxicity of contaminated soils is monitored, the avoidance test should be considered as screening test and carried out in conjunction with toxicity tests (Hund-Rinke et al., 2003).

Based on our results, it is concluded that earthworm avoidance tests, which are simple and rapid, offer an efficient screening tool to determine the impact of adding biosolids to the soil. The tests can detect differences between different biosolids, but stimuli not related to toxicity that could alter earthworm behaviours need to be monitored in future studies. The use of natural field soil is recommended because it creates more realistic conditions, but standardisation is reduced. Regarding the choice of earthworm species, the results of this study confirm the suitability of $E$. fetida for biological screening of biosolids. For assessing the toxicity of biosolids, E. fetida, L. terrestris and $A$. caliginosa are ecologically relevant species and they are sensitive to biosolid applications. However, when a rapid and efficient screening is required, cultured E. fetida are much more convenient.

\section{REFERENCES}

Amorim M.J.B., Römbke J. and Soares A.M.V.M. (2005), Avoidance behaviour of Enchytraeus albidus: effect of benomyl, carbendazim, phenmedipham and different soil types, Chemosphere, 59, 501-510.

Amorim M.J.B., Novais S., Römbke J. and Soares A.M.V.M. (2008), Avoidance test with Enchytraeus albinus (Enchytraeidae): effects of different exposure time and soil properties, Environmental Pollution, 155, 112-116.

Bouché M.B. (1977), Strategies Lombriciennes, Ecological Bulletin, 25, 122-132.

Butt K.R. (1999), Effects of thermally dried sewage granules on earthworms and vegetation during pot and field trials, Bioresource Technology, 67, 149-154.

Carbonell G., Pro J., Gómez, Babín M.M., Fernández C., Alonso E. and Tarazona J.V. (2009), Sewage sludge applied to agricultural soil: Ecotoxicological effects on representative soil organisms, Ecotoxicology and Environmental Safety, 72, 1309-1319.

Contreras-Ramos S.M., A'Ivarez-Bernal D. and Dendooven L. (2009), Characteristics of earthworms (Eisenia fetida) in PAHscontaminated soil amended with sewage sludge or vermicompost, Applied Soil Ecology, 41, 269-276.

Crouau Y., Gisclard C. and Perotti P. (2002), The use of Folsomia candida (Collembola Isotomidae) in bioassays of waste, Applied Soil Ecology, 19, 65-70.

Curry J.P. (1994), Grassland Invertebrates. Ecology, Influence on Soil Fertility and Effects on Plant Growth, Chapman \& Hall, London, $437 \mathrm{pp}$.

Curry J.P. and Schmidt O. (2007), The feeding ecology of earthworms - A review, Pedobiologia, 50, 463477.

Domene X., Alcaiz J.M. and Andrés P. (2008), Comparison of solid-phase and eluate assays to gauge the ecotoxicological risk of organic wastes on soil organisms, Environmental Pollution, 151, 549-558.

Doube B.M., Schmidt O., Killham K. and Correll R. (1997), Influence of mineral soil on the palatability of organic matter for lumbricid earthworms: a simple food preference study, Soil Biology and Biochemistry, 29, 569-575.

EC (European Commission), (2000), Working Document on Sludge $-3^{\text {rd }}$. Draft, Directorate-General Environment, Brussels, DG ENV.E.3/LM.

EC (European Commission), (1991), Council Directive 91/676/EEC of the 12 December 1991 on the protection of waters against pollution caused by nitrates from agricultural sources.

EC (European Commission), (1986), Council Directive 86/278/EEC of 12 June 1986, on the protection of environment, and in particular of the soil, when sewage sludge is used in agriculture, OJ L, 181.

Frampton G.K., Jansch S., Scott-Fordsmand J.J., Rombke J. and van den Brink P.J. (2006), Effects of pesticides on soil invertebrates in laboratory studies: a review and analysis using species sensitivity distributions, Environmental Toxicology and Chemistry, 25, 2480-2489.

Garcia M., Römbke J., Torres de Brito M. and Scheffczyk A. (2008), Effects of three pesticides on the avoidance behaviour of earthworms in laboratory tests performed under temperate and tropical conditions, Environmental Pollution, 153, 450-456.

Gray N.F. (2005) Sludge Treatment and Disposal, Water Technology (Second Edition), pages 572-602.

Hamilton D.J., Dindal D.L., Parkinson C.M. and Mitchell M.J. (1988), Interaction of earthworms species in sewage-sludge-amended soil microcosms: Lumbricus terrestris and Eisenia fetida, Journal of Applied Ecology, 25, 847-852. 
Hund-Rinke K. and Wiechering H. (2001), Earthworm avoidance test for soil assessments. An alternative for acute and reproduction tests, Journal of Soils and Sediments, 1, 15-20.

Hund-Rinke K., Achazi R., Römbke J. and Warnecke D. (2003), Avoidance test with Eisenia fetida as indicator for the habitat function of soils: results of a laboratory comparison test, Journal of soils and Sediments, 3, 7-12.

Hund-Rinke K., Lindemann M. and Simon M. (2005), Experiences with Novel Approaches in Earthworm Testing Alternatives, Journal of Soils and Sediments, 5, 233-239.

Kobetičová K., Hofman J. and Holoubek I. (2010), Ecotoxicity of wastes in avoidance tests with Enchytraeus albidus, Enchytraeus crypticus and Eisenia fetida (Oligochaeta), Waste Management, 30, 558-564.

Langdon C., Hodson M.E., Arnold R.E. and Black S. (2005), Survival, Pb-uptake and behaviour of three species of earthworm in $\mathrm{Pb}$ treated soils determined using an OECD-style toxicity test and a soil avoidance test, Environmental Pollution, 132, 368-375.

Lo K.S.L. and Chen Y.H. (1990), Extracting heavy metals from municipal and industrial sludges, Science of Total Environment, 90, 99-116.

Lukkari T. and Haimi J. (2005), Avoidance of Cu- and Zn-contaminated soil by three ecologically different earthworm species, Ecotoxicology and Environmental Safety, 62, 35-41.

Lukkari T., Marjo Aatsinki M., Väisänen A. and Haimi J. (2005), Toxicity of copper and zinc assessed with three different earthworm tests, Applied Soil Ecology, 30, 133-146.

Metcalf and Eddy, (2003), Wastewater Engineering: Treatment, Disposal and Reuse, fourth ed. McGrawHill Publish Company Ltd, New York.

Moreira R., Sousa J.P., Canhoto C. (2008), Biological testing of digested sewage sludge and derived composts, Bioresource Technology, 99, 8382-8389.

Natal-da-Luz T., Ribeiro R. and Sousa J.P. (2004), Avoidance tests with collembola and earthworms as early screening tools for site specific assessment of polluted soils, Environmental Toxicolology and Chemistry, 23, 2188-2193.

Natal-da Luz T., Tidona S., Jesus B., Morais P.V. and Sousa J.P. (2009), The use of sewage sludge as soil amendment. The need of an ecotoxicological evaluation, Journal of Soils and Sediments, 9, 246260.

Ozores-Hampton M., Stanslay P.A. and Obreza T.A. (2005), Heavy metal accumulation in a sandy soil and in pepper fruit following long-term application of organic amendments, Compost Science Utilisation, 13, 60-64.

Owojori O.J. and Reinecke A.J. (2009), Avoidance behaviour of two eco-physiologically different earthworms (Eisenia fetida and Aporectodea caliginosa) in natural and artificial saline soils, Chemosphere, 75, 279-283.

Pandard P., Devillers J., Charissou A.M., Poulsen V., Jourdain M.J., Férard J.F., Grand C. and Bispo A. (2006), Selecting a battery of bioassays for ecotoxicological characterisation of wastes, Science of the Total Environment, 363, 114-125.

Römbke J. and Amorim M. (2004), Tackling the heterogeneity of soils in ecotoxicological testing: A eurosoil based approach, Journal of Soils and Sediments, 4, 276-281.

SAS. (2004), User's Guide, Version 9.1. Cary, NC, USA: SAS Institute Inc.

Schaefer M. (2003), Behavioural endpoints in earthworm ecotoxicology - Evaluation of different test systems in soil toxicity assessment, Journal of Soils and Sediments, 3, 79-84.

S.I. No. 183/1991 - European Communities (Use of Sewage Sludge in Agriculture) Regulations, 1991.

S.I. No. 148/1998 - Waste Management (Use of Sewage Sludge in Agriculture) Regulations, 1998.

S.I. No. 267/2001 - Waste Management (Use of Sewage Sludge in Agriculture) (Amendment) Regulations, 2001.

S.I. No. 378/2006 - European Communities (Good Agricultural Practice for Protection of Waters) Regulations 2006.

Spurgeon D., Svendsen C., Rimmer V.R., Hopkin S. and Weeks J.M. (2000), Relative sensitivity of lifecycle and biomarker responses in four earthworm species exposed to zinc, Environmental Toxicology and Chemistry, 19, 1800-1808.

Stephenson G.L., Kaushik A., Kaushik N.K., Solomon K.R., Steele T. and Scroggins R., (1998), Use of an avoidance-response test to assess the toxicity of contaminated soils to earthworms. In: Sheppard, S.C., Bembridge, J.D., Holmstrup, M., Posthuma, L. (Eds.), Advances in Earthworm Ecotoxicology. SETAC Press, Boca Raton, FL, pp. 67-81.

Strasser H., Brunner H. and Schinner F. (1995), Leaching of iron and toxic heavy metals from anaerobically-digested sewage sludge, Journal of Industrial Microbiology and Biotechnology, 14, 281187. 
Tomlin, A.D. (1992), Behaviour as a source of earthworm susceptibility to ecotoxicants. In: P.W. GreigSmith, H. Becker, P.J. Edwards, F. Heimbach (Eds.), Ecotoxicology of earthworms. Intercept, Hants, pp. 116-125.

Yeardley R.B., Lazorchak J.M. and Gast L.C. (1996), The potential of an earthworm avoidance test for evaluation of hazardous waste sites, Environmetal Toxicology and Biochemistry, 15, 1532-1537. 